\title{
Research on Color Planning of Yantai Based on Regional Culture
}

\author{
Wenting Lu \\ Yantai Nanshan University \\ Yantai, Shandong, China 265713
}

\author{
Hao Pei \\ Yantai Nanshan Vocational Technical School \\ Yantai, Shandong, China 265713
}

\begin{abstract}
As one of the key factors for revealing urban image and urban culture, on the background of globalization and urbanization, due to the weakening and even vanishment of regional culture, urban color manifests a convergent tendency. This paper proposes regional planning principles and planning strategies through discussing mutual relationship between regional culture and urban color design and comprehensively taking account into historic context, physical geographic environment and other many region factors of Yantai.
\end{abstract}

Keywords—regional culture; urban color; Yantai

\section{INTRODUCTION}

As the carrier of human civilization, cities cannot be separated from diversified regional environment. Cities with different regional environment also show colorful and distinctive features when providing physical environment for the survival and development of mankind. However, along with industrial development and expedite proceedings of urbanization development, regional culture and urban individual character of cities in our country is gradually lost, urban culture is gradually eroded by international culture, urban regional characteristics gradually runs off; urban image is gradually converging, without identifiability any longer; it is very difficult for people to find sense of belonging according to urban characterization. In that case, maintenance and regression of urban image is more and more prominent. Regional culture is one of key factors for revealing urban image and urban color is an important visual perception factor of urban image, which are effective way to reflect regional culture and keep urban characteristics. Good urban color design does not only bring good visual enjoyment to people and improve overall image of the city, but also plays an active role in heritage and development of urban regional culture. The author proposes to take Yantai as an example and discusses research on urban color planning starting from regional culture.

\section{REgionAl CUlture AND URBAN COLOR DESIGN}

\section{A. Regional Culture Includes Urban Color}

Region refers to certain specific area. Regional culture refers to product under combined action of natural factors and human factors in certain regional condition, which is determined by factors such as climate characteristics, historic customs, religious belief, traditional folklore and local cultures of a region.

Regional culture difference is formed due to difference of physical geographic environment and difference of people's lifestyle, religious belief, thought morals mode in different regions. These factors become main factors to influence regional culture, among which color factor also forms respective preference and regional difference, for example, the northern area prefers distinct contrast and intense color; the southern area prefers clean and elegant decoration color.

\section{B. Regionalism of Urban Color}

As one part of urban cultural landscape, urban color is accumulated in historical culture development. It directly reflects overall scene and historic content of a city and becomes historical cohesion of natural ecology and social life process and even the true representation of regional characteristics. Although urban color is closely linked to natural environment, such as specific urban landform, season and climate, peculiar plants and so on, urban color is not simple natural color, but summation of natural color and humanistic color formed and expressed during interaction with nature, such as custom, culture, and traditional building, etc. For example, Paris France, a city owns thousands of years old buildings at each stage, and most of its buildings include silver grey roof, beige wall face, supplemented with light color door and window cover and black iron, and the total tone is unified, therefore, Paris is always called a "beige city".

Urban color accumulates urban history, thereinto, some are results of natural selection, such as grey tiles and white wall in South China cities, some are reflection of politics, economy and culture, such as color contrast between golden roof in Beijing imperial palace and grey tiles roof of Beijing old courtyard dwelling house, which is the symbol of supreme imperial power in Chinese feudalism society. They meet color matching of aesthetics laws. They are products of aesthetic taste in different countries and different nationalities, and form different regional culture and tradition. However, if a city destroys the tradition arbitrarily, which means it is isolated from history and will lose its due cultural deposits. Therefore, inheritance of regional urban color is requirement of cultural diversity as well as specific embodiment of cultural diversity in city. 


\section{ANALYSIS ON REGIONAL ELEMENTS OF YANTAI}

Regional elements of a city refers to geographic background of a city, including geology, landform, climate, soil, hydrology and other physical geographic environment, as well as local history, society, economy, culture and other humanistic characteristics. They are internal culture and romantic charm for a city to form distinction and features, which cannot only arouse mentality resonance of urban public, but also possess value of further inheritance and development.

\section{A. Physical Geographic Environment of Yantai}

Physical geographic environment is an important element of urban image, and it also deeply influences behavior of local residents and local historical and cultural tradition.

Yantai is near the mountain and by the sea, and the natural scenery is beautiful. It mainly includes littoral environment and mountain environment. As an important coastal city in northeast Shandong Peninsula, Yantai is close to Bohai Sea and Yellow sea, with total coastline of $909 \mathrm{~km}$. Landform in Yantai is mainly low mountains and hills, hills are gently undulating, and the forest is verdant. Mian mountains include Kunyu Mountain, Daze Mountain, Yanshan Mountain and Aishan Mountain, etc. The highest mountain Kunyu Mountain is a representative element of Yantai urban context as Yantai birthplace and symbol. Special wrap-around feature regional landscape of "mountain, sea, city and island" forms friendly and pleasant coastal urban landscape.

\section{B. Historical and Cultural Tradition of Yantai}

1) "Celestial" culture: Possessing Taoist historical site and rich "celestial" cultural atmosphere, Yantai is cradle of eastern tale. From "Dengzhou mirage", "Mount Sanshen" legend, the tour of First Emperor of Qin, Xu Fu s Eastward Sailing to The Eight Immortals Crossing the Sea, "celestial" culture has huge radiation for Shandong Peninsula and even the whole Shandong province. Ocean and mist create illusoriness, interesting artistic conception and unique fun of mountain, sea, city and island and form leisure and form quiet and elegant urban atmosphere, and become bright scenery of Chinese immortal culture.

2) Wine culture: Yantai accumulates pure wine culture. With 111 years history, Yantai Changyu Wine-making Company has creating a pioneer of wine industry in China and is the only one wind enterprise with export in our country. In addition, Changyu establishes the first specialized wine chateau in China, gathering tourism, tour, relaxation and entertainment together and becomes spreading position of wine culture. Yantai international wine festival held from 2007 highlights Yantai wine culture and manifests urban characteristics, promotes popularity of Yantai across the country and the world and enriches historical and cultural significance of the city.

\section{PlanNing PRINCIPLES FOR URBAN REgional COLOR} OF YANTAI

\section{A. General Principles of Color Planning and Design}

Urban color planning and design must reflect the requirements of people first, protect natural ecological environment, follows the principles of respecting local characteristics of different regions, and respecting urban context and stress unified harmony of overall design.

1) Inheritance principle: Inheritance principle is the primary condition of reflecting regionalism and fundamental idea of urban sustainable development. It expresses profound humanistic concern and natural ecological concept during urban color planning and is the root of urban development in highly complex and frequently varying reality situation. Inheritance planning principle requires people to take full consideration of original living habit during urban construction, find ideological root running through urban color construction with customary living idea, seek urban development mainline and conduct reasonable urban color planning. By adopting inheritance planning idea, people can grasp urban times characteristics in deep cultural deposits of city, accurately determine urban image, examine urban development direction in dynamic perspective, combine modern planning method and blend urban traditional characteristics into urban color planning so as to avoid people's blind following suit and loss of urban construction continuity and realize urban sustainable development.

2) Systematic principle: Urban space is a complex comprehensive system. Objective of urban color planning is to obtain urban reasonable development in harmony. Planning process of urban color just forms a unified urban color and establishes a relatively steady urban color frame through integration of all elements. Systematic planning runs through the whole process of color planning, integration of traditional culture and modern culture shall be emphatically considered; secondly integration of historic content and modern site shall be paid into attention to. Starting from systematic principle, mutual status and role of all factors in urban color planning shall be considered. Targeting at urban color planning, harmony with natural environment color shall be taken into consideration for architectural color and harmony with urban constant color shall be taken into consideration for urban non-constant color. In all elements of urban planning, urban architecture is relative invariant factor. Therefore, architectural color plays an important role in urban color planning.

3) Harmonization principle: Control elements of urban color include resources, energy, materials, climate, air temperature, politics, culture, science and technology, physiology and psychology, etc. [1], which are dominant force for change of urban color. Various urban colors interact and interplay with each other and mutually form urban color landscape. Characteristics among elements shall be taken full consideration during urban color planning and primary and secondary relationship among them shall be concluded and coordinated and utilized. 


\section{B. Adoption Principles of Regional Color}

1) Application principle of humanistic color: Urban color possesses "culture". Regional culture reflecting on urban color makes the city have more in-depth insight of history; reasonable expression of urban color culture can increase urban orderliness and acquire people's cultural identity and make the city more charming. Cultural color represents color tradition inheriting from history to now; therefore, reasonable application and reflection in urban color environment is conductive to building urban culture atmosphere. The human factors are converted to representative color for application through extraction and abandonment so as to fully reflect regionalism of color. Humanistic color is mainly reflected in urban environment color, that is, urban identification color and street facilities colors, etc.

2) Application principle of natural colors: Natural colors are rich and beautiful, for example, forest, river, lake, sea, blue sky, land and so on are inalterable urban elements in surroundings. Urban color will never compete with natural colors forever, but shall be harmonious with natural colors; man is an integral part of nature and urban color shall be blended in natural environment. Generally, dominant hue of urban color shall adopt color scheme fused with natural colors, that is, color scheme which has the same hue with natural colors or adjacent hue shall be taken as dominant hue of urban color. Natural colors can constitute primary color, adjunctive color, intersperse color or urban environment color through saturation and brightness change.

\section{Regional CUlture-BASED STRATEGIES ON COLOR} PLANNING OF YANTAI

\section{A. In Harmony With Natural Environment, Taking Full Consideration Into Landform Characteristics of The City}

Yantai is a city with hills and waters, where "mountain, sea, city and island" are viewing platform. Therefore, color processing of urban building roof is very important. For the matching of urban architectural color and natural hills and waters colors: coastal buildings adopt blue grey tiles roof, white wall face, harmonious with the sea and blue sky and then refreshing and quiet effect is obtained. In hills and mountainous regions, the buildings adopt hue contrast, mainly including red, warm grey and so on, which matches with natural background colors so as to build strong visual perception.

\section{B. In Harmony with History Humanities, Highlighting Urban Regional Characteristics}

Through analysis on urban size, historical culture and urban characteristics of Yantai, Yantai possesses rich natural and humanistic landscape resources. Fusion and coordination between new colors and traditional colors shall be focused on during urban color design of Yantai, that is, relationship between new buildings and old town. During urban development process, only urban environment and traditional buildings are protected well and urban new buildings and old building are harmonious can strong local features and dense cultural atmosphere be formed. For example, buildings style and features of Yantai old town has been basically formed. Therefore, in urban color design, new buildings can follow original color style as a whole, continue colors matching of white and multiple grey series wall face, red and grey roof. It is suggested that Paving colors of square and street adopt original Yantai chipped ashlar and quartzite to replace the current pavement, and the colors are mainly grey and steel grey.

\section{In Harmony With Space Atmosphere in Urban Function Area}

It is unrealistic to only stress one color in the whole city. Urban colors harmonious with atmosphere in each urban section shall be determined according to functional localization and natural environment characteristics of each district. The color scheme harmonious with space atmosphere of each district can be determined according to urban functions, environmental conditions and urban structure. Yantai is mainly divided into Zhifu District, Laishan District, Kaifa District, Fushan District and Muping District. Each district has its own characteristics. It is necessary to build bustling space atmosphere in commercial area, therefore, lively color can be taken as dominant hue, matched with the same color scheme as complementary hue so as to form fresh and bright tone of commercial area. For color of coastal area, the situation in conflict with blue sky and blue water shall be avoided. Transition effect gradually varied from seaside to inland can be adopted, for example, cold tone with low brightness and low saturation is transited to modern, lively and strong warm tone. Urban color shall be change from tradition to modern nature and coloring tact of consistent "pink, light, floating, timid" in urban color design shall be abandoned to reflect mass feeling and sunshine feeling. Specific to various buildings, for historic, literature and art and antique buildings, the colors shall inherit traditional architectural color characteristics in Yantai region; for buildings in commercial and financial areas, lively warm tone shall be given to priority; for buildings in inhabiting leisure club, blue, red and other high clarity tone shall be given to priority; for office, science and education, sports and recreational and athletic buildings, tertiary colors of cream and light brown can be taken into consideration.

\section{CONCLUSION}

As an important aspect of urban image and important carrier of urban regional culture, urban color plays a unique and irreplaceable role in shaping urban image and inheriting regional culture, etc. Especially on the background of globalization and urbanization and under the new condition that Chinese urban construction enters rapid development, facing the reality of urban color disorder and characteristics loss, urban color design strategies based on regional culture is an effective way to solve urban color problem currently. Through the research on urban color planning of Yantai, perfect urban color planning system shall be established and urban style with regional characteristics shall be moulded so as to bring harmonious living environment for the city. 


\section{REFERENCES}

[1] SUN Xuyang. City Color Planning Research Based on Regionality[D]. Shanghai: Tongji University, 2006

[2] JIAO Yan. Performance and Planning of Urban Architectural Color[J], Urban Planning, 2001

[3] YIN Sijin. Planning and Design of the City's Colorscape[M]. Nanjing: Southeast University Press, 2004 